\title{
Kulturmøter i psykisk helsevern
}

\author{
Møtet mellom flyktninger med psykiske lidelser \\ og behandlingsapparatet byr på mange utfordringer.
}

$\mathbf{M}$ itt mål med denne artikkelen er å undersøke flyktningers erfaringer og opplevelser i møte med det norske psykiatriske behandlingsapparatet. Jeg tar sikte på å få fram tanker, erfaringer og holdninger fra kommunikasjonen og meddelelser mellom aktørene. Informantene i undersøkelsen hevder at fagpersoner i behandlingsapparatet og flyktninger ofte har ulik forståelse av psykiske lidelser, årsaker til disse og behandlingsmetoder. Mange flyktninger er skeptiske til behandlingen de får hos psykolog eller psykiater, og til at de kan få hjelp av dem. Enkelte flyktninger følger behandlingen på grunn av pliktfølelse og lydighet mot autoriteter. Å motsette seg behandling er uhøflig mot dem som henviser og mot behandleren. Noen forstår ikke hva tilbudet innebærer, andre opplever møtet med psykolog eller psykiater som en invadering av det private rom.

\section{Flere flyktninger}

Det globale presset har påvirket norske myndig-

\section{Hovedbudskap}

Artikkelen fokuserer på det ofte vanskelige møtet mellom ansatte innen psykisk helsevern og pasienter med flyktningbakgrunn. Artikkelen belyser de utfordringer og dilemmaer som gjerne oppstår i slike møter. Selv om det her dreier seg om et terapeutisk møte, er det på samme tid et kulturmøte.

\section{Søkeord}

Les mer og finn litteraturhenvisninger på våre nettsider. ) Helsevesen \ Kultur / Flyktning heter til å motta blant annet kvoteflyktninger. I en periode fant et større antall individuelle asylsøkere veien til Norge. Noen av dem ble innvilget asyl eller opphold på humanitært grunnlag, men like mange fikk avslag og ble sendt ut av landet. De siste 30 årene har det vært en økende strøm av flyktninger til Norge. På grunn av det økende antallet kommer stadig flere fagpersoner, innen ulike profesjoner, i kontakt med flyktninger. Dette gjelder også fagpersoner innen mottaksapparatet, helsetjenesten, sosialkontor, barnevernet, skoler og utdanningsinstitusjoner. Psykologer og psykiatere kommer inn i bildet dersom problemene er av en slik art at de ikke kan løses praktisk ved hjelp av nettverket eller i samhandling med de personer som skal overta førstehåndshjelpen. Det finnes fortsatt fagpersoner innen behandlingsapparatet i Norge som ikke har erfaring med flyktninger eller ser kultur eller flerkulturell forståelse som et viktig ledd i planleggingen av behandlingen. Et viktig spørsmål å stille da er: Hvilke kulturelle forståelsesrammer fremmer eller hemmer dialogen mellom behandler og flyktning/pasient i norsk helsevesen?

\section{Teoretisk perspektiv}

Hvis man snakker om møtet mellom behandler og pasient som et kulturmøte, legger man en tverrfaglig tilnærming til grunn for møtet i behandlingsapparatet. Den allmenngyldige definisjonen på kulturmøte står for personens beskrivelse av møtet med personer som har et annerledes tankesett og andre normer for atferd. Å beskrive kommunikasjonen mellom behandler og flyktning som et kulturmøte kan gi inntrykk av et syn på kultur som noe statisk og fiktivt eller rigid, der de møtende er bærere av nedarvete kulturmønstre. Et annet syn på kultur er at den stadig endres. Behandler og pasient møtes med sine ulike kulturelle bakgrunner og hvert sitt utgangspunkt. Møtet gjør at begge parter endrer seg litt, man åpner og fornyer seg, og det skjer en revidering av den ene partens syn på den andre og vise versa.

I kulturelle endringsprosesser utvikler behandler og flyktning/pasient nye mønstre som skapes i møtet mellom ulike tankesett og strategier. Behandler og flyktning/pasient får roller som aktive aktører i en kulturskaperprosess i stedet for å være passive kulturbærere. Dermed vil de betrakte møtet som en pågående endringsprosess. Men dette skjer ikke av seg selv. For å oppleve kulturmøtet som pågående endringsprosess må de møtende gripe inn på ulike måter, og de må ha et ønske om å gjennomføre møtet. De må ha vilje til dialog. De må ha et ønske om å åpne seg opp for den andre, for på den måten å legge grunnlaget for endring.

\section{Metode}

Ettersom innvandringen til Norge har økt, har også omfanget av forskningsarbeider på det psykososiale feltet $ø \mathrm{kt}(1-6)$. Undersøkelsen artikkelen bygger på er basert på et kulturanalytisk og etnologisk perspektiv og utført ved hjelp av kvalitative undersøkelsesmetoder; intervju og observasjon. I perioden fra 1995 til 1996 foretok jeg en intervjuundersøkelse blant ulike fagpersoner ved et psykiatrisk sykehus og en psykiatrisk avdeling ved et annet syke- 
LIDER I STILLHET: Blant flyktninger er det færre kvinner enn menn som går til behandling for psykiske lidelser. En av legene som er intervjuet $i$ denne undersøkelsen mener kvinner som for eksempel har blitt voldtatt vegrer seg for å oppsøke hjelp før de blir alvorlig psyisk syke. Illustrasjonsfoto: Colourbox

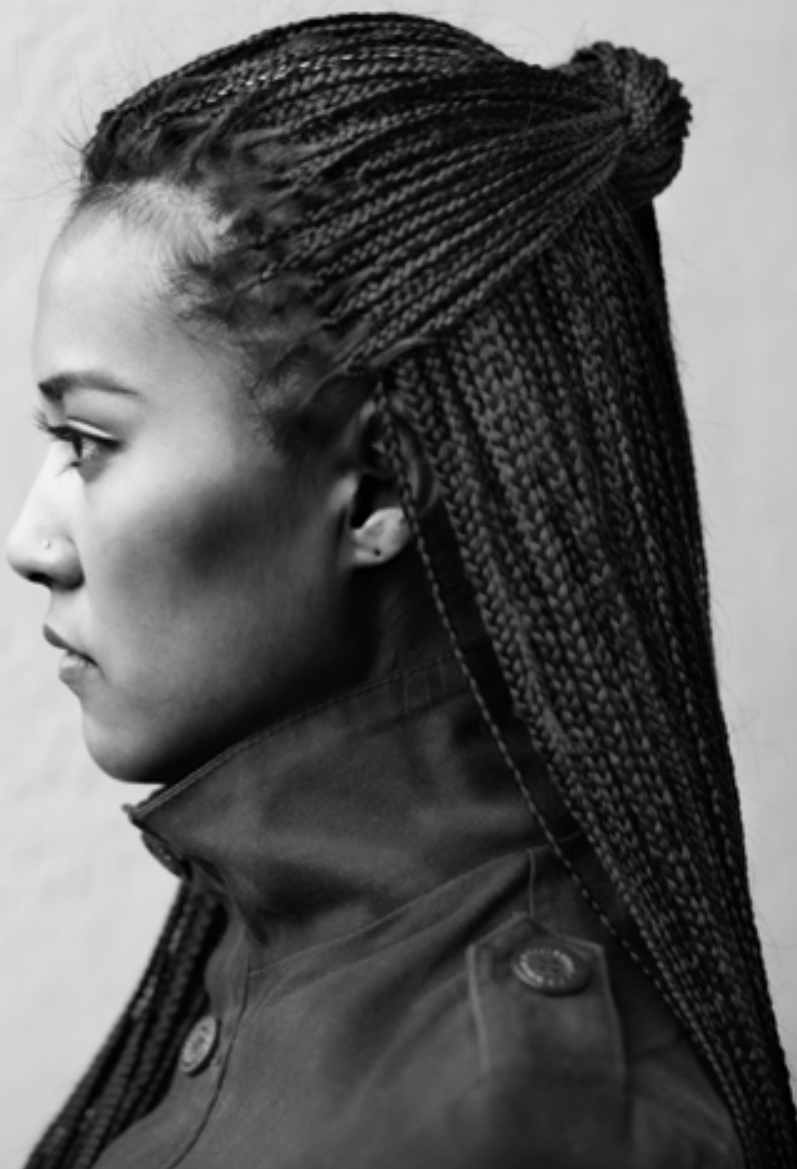

hus, begge i Vestlandsregionen. Fagpersonene hadde til felles at de behandlet nyankomne flyktninger med psykiske symptomer og lidelser. Av ulike årsaker ble den første empiriske undersøkelsen aldri publisert. Bortsett fra at den er viktig i historisk perspektiv, er det også interessant å intervjue noen av de samme fagpersonene for å se hva som har endret seg på dette feltet, og om det overhodet har endret seg. Derfor ønsket jeg å foreta en mindre undersøkelse i 2011, hvor jeg hadde mer uformelle samtaler med noen av de samme fagpersonene som ble intervjuet i 1995. Disse fagpersonene er i dag tilsatt i de Regionale ressurssentre om vold, traumatisk stress og selvmordsforebygging (RVTS). To av dem svarte på spørsmål via post. Hensikten var å undersøke hvorvidt disse fagpersonene ser noen av de samme mønstrene for samhandling mellom fagperson og pasient i dag som i 1995 , og hva de tenker hemmer eller fremmer dialog og kulturmøteprosesser.

\section{Informanter}

Den første undersøkelsen besto av intervjuer med 12 informanter med ulike profesjoner innen psykisk helsevern; lege, sykepleier, sosi- onom, psykolog og psykiater. Informantene gir sin versjon av hvordan de opplevde møtet med flyktninger og eventuelt deres familie i psykisk helsevern. Det er altså beskrivelsene av kulturmøtet mellom behandler og pasient/flyktning som er vektlagt i undersøkelsen. Intervjuene ble gjennomført på informantens arbeidsplass og varte i gjennomsnitt to timer. Intensjonen med intervjuene var at informantene skulle få mulighet til å formulere hva arbeidet med flyktningene innebar for dem og hvordan de opplevde møtene - hva de eventuelt erfarte som hemmet eller fremmet dialogen i kulturmøtet. Spørsmålene berørte temaer knyttet til arbeidet generelt samt mer konkrete beskrivelser av det aktuelle kulturmøtet med pasienten. Flere av disse fagpersonene har lang arbeidserfaring innen sitt felt, også når det gjelder flyktninger. Informantene var alle tilsatt ved de nevnte institusjoner som mottok flyktninger til behandling

\section{Behandling}

På tross av at flere av fagpersonene har lang erfaring med behandling av norske pasienter med psykiske lidelser, sier de at de likevel er usikre på metoder og behandling når det gjel- der pasienter med annen etnisk og kulturell bakgrunn og hva som er riktig tilnærming til deres problemer. De er usikre på hva i prosessen som kan tilskrives flukt, migrasjons- og diasporaprosesser, og hva som eventuelt kan forklares på annen måte. Enkelte vektlegger

\section{«De fleste flyktningene som henvises til psykiatrien er enslige.»}

pasientens familienettverk, og at familiemedlemmer kan bidra positivt til behandlingen. Flyktningene og deres familier har sin egen forståelse og definisjon av lidelsene sine.

\section{Tolkens rolle}

En viktig funksjon i møtet mellom behandler og pasient/flyktning, er tolking, og tolkens rolle i møtet. I arbeidet med flyktninger er bruk av tolk vanlig og ofte helt nødvendig for å forstå og bli forstått. Tolkens rolle og hvem tolken er, kan ha stor betydning for hvordan behandlingsmøtet forløper og for om pasienten åpner seg for behandleren. Man må derfor 
vie forhold som omhandler tolk og bruk av tolk oppmerksomhet og ta det med i vurderingen etter møtet med klienten. Det er viktig at tolken er profesjonell.

\section{Dialog}

Kunnskap om arbeid med flyktninger blir erfart gjennom praksis og over tid. Etablering av tillit mellom pasient og behandler legger det første grunnlaget for positive kulturmøter mellom partene. Med kultur tenker jeg her på de møtende parters ulike etniske referanser. Det kan også referere til partenes ulike kulturelle møtepraksiser, hvor de stiller med ulike forventninger til hverandres roller avhengig av den kunnskap og erfaring som hver av dem har med seg til møtet. Begreper som psykolog og psykiatri blir av mange i denne

\section{«Mange flyktninger synes å ha utviklet psykiske lidelser i eksil.»}

pasientgruppen forbundet med galskap, skam, innesperring, utestenging, stigmatisering eller straff, herunder også straff som en følge av politisk virksomhet. Jeg vil i den sammenheng belyse hvordan ulike forståelsesrammer legger til rette for eller hindrer at dialog oppstår. Det dialogiske perspektivet legges til grunn for et utvalg fortellinger eller «biografier» som anskueliggjør det mangfold av individer og livsløp som flyktningene representerer. Det er en tendens til å betrakte flyktningene som en homogen gruppe. Det er viktig å framheve at det finnes faktorer som forener dem, men at det er minst like mange som gjør dem ulike. Dette gjelder også det enkelte individs eller families evne og mulighet til selv å giøre noe med sin livssituasjon.

\section{Tilbud}

Det finnes mye skjult psykisk lidelse blant flyktninger og mange kommer ikke i behandling før de er svært dårlige. Årsakene er sannsynligvis mange og komplekse. Enkelte flyktninger kan være vanskelig å hjelpe, men for de aller fleste som utvikler psykiske lidelser, skulle det være mulig å gi et tilbud. Jeg tenker da både på individuelle tilbud og på tilbud som omfatter familier. Tilbud kan være rettet mot barn og ungdom i familier, eller mot enslige barn og unge som har opp- levd traumatiske opplevelser i forbindelse med flukt, men det kan også omfatte barn som er født i eksil.

\section{Barn}

Behandlere opplever av og til at en pasient kan være frustrert og gi uttrykk for dette med aggressiv atferd. Andre kan gi uttrykk for bitterhet, kanskje fordi tilværelsen i eksil ikke innfridde forventningene de hadde. Også barn og ungdom kan gi uttrykk for frustrasjon og sinne, ikke sjelden får det konsekvenser i skolesituasjonen og virker inn på konsentrasjon og oppmerksomhet, atferd, sosial tilpasning og samhandling. Barna påvirkes av foreldrenes problemer, som slår dobbelt tilbake på dem. At både foreldre og barn lider, bringer familien inn i en ond sirkel. En psykiater har følgende eksempel på dette: «En gutt ble henvist til barnepsykiateren etter at problemene på skolen var blitt så alvorlige at læreren ikke taklet dem. Læreren innkalte mor til samtale og fortalte at gutten var urolig og ukonsentrert. Læreren ba moren snakke med ham. Han mente også at gutten burde henvises til PPT. Mor hadde ingen kunnskap om PPT og ingen ga henne informasjon heller. Morens håndtering av situasjonen var å gi gutten straff. Han fikk ikke se på TV, han fikk heller ikke gå ut. Som forventet hadde tiltakene liten effekt i den foreliggende situasjonen, og atferden fortsatte som før. Etter en tid ble gutten henvist til psykiatrien».

\section{Kunnskap}

Manglende kunnskap, misforståelser og skepsis gjør veien til behandlingsapparatet unødvendig lang, men skepsis og mistillit skaper også behandlingsmessige dilemmaer. Noen flyktninger har vært utsatt for misgjerninger utenfor vår fatteevne. Misgjerningene kan i tillegg være forbundet med skam. Eksempler kan være: Tortur, tap av ære, overgrep, eller voldtekt. En annen psykiater sier: «Fortellingene deres beretter om en virkelighet som ligger langt fra vår egen. Det er ikke lett å få tak i de kulturelle kontekster eller å forstå de innebygde kulturelle sammenhenger. Dette vanskeliggjør tiltaksarbeidet. I tillegg er mange flyktninger også skeptiske til norske behandleres tiltak, eller de vegrer seg for å fortelle hva de har opplevd».

Mange behandlere etterlyser som nevnt mer kunnskap og det å kunne fordype seg i spørsmål omkring flyktningenes bakgrunn.
Dette er for å kunne møte dem mer forberedt, med bedre tilnærminger til deres problemer og med større forståelse.

\section{Nettverk}

Det sosiale nettverket er et velkjent begrep innen psykiatrien. Et slikt nettverk, som kunne vært en styrke i tiltak og oppfølgingsfasen, kan være utilgjengelig for denne pasientgruppen av flere årsaker. Blant annet kan nettverket mangle helt, være svakt eller vanskelig å kartlegge. En årsak til at det er svakt kan være brudd med nettverket som følge av åpenlyse eller skjulte årsaker. En psykiater beretter om dette: «Kartlegging av nettverk i Norge og eventuelt også i flyktningenes hjemland, er en vesentlig del av arbeidet. Som terapeut er det viktig å finne ut hvem personen var før han kom til Norge, selv om slik kartlegging kan ta tid og kompliseres ved at flyktningene ofte er svært dårlige og står midt i et livskaos.

De fleste flyktningene som henvises til psykiatrien er enslige. Noen av dem har kanskje forsøkt å etablere familie i Norge, men har mislyktes i dette. En av informantene meddeler: «Felles for flyktningene er at det sosiale nettverket rundt dem er svakt eller mangler helt. De blir sårbare, noe som kan vanskeliggjøre sosial samhandling, i forhold til egne landsmenn og i forhold til nordmenn». Når situasjonen er slik gir det liten mening for pasienten å snakke om nettverkets betydning, funksjon og rolle. Det stiller imidlertid ytterligere krav til behandler og de instanser som skal følge opp pasientene i ettertid. I denne fasen er det ofte avgjørende at det finnes eller etableres et nettverk rundt flyktningen.

\section{Ensomhet}

Personer som skal følge opp prosessen med nettverksstyrking eller nettverksetablering, bør ha noe kunnskap om flyktningenes bakgrunn, deres etniske, kulturelle, religiøse, og eventuelt politiske forankring. Spørsmålet blir da hvordan behandlere kan innhente slik kunnskap og hvordan de best kan iverksette behandling eller tiltak ut ifra en slik kunnskap. Det er lett å forestille seg at flyktninger som kommer fra samme land også har et felles nettverk. Dette stemmer ikke alltid. I grupper med svakt eller manglende nettverk er det nødvendigvis ikke mangel på andre landsmenn som er problemet, men at perso- 
nen av ulike grunner velger å holde avstand til disse. Motsatt hender det også at nettverket holder personen på avstand. Felles etnisk eller nasjonal opprinnelse er ingen garanti for medlemskap og inkludering i fellesskapets nettverk. Nettopp innen etniske eller nasjonale grupper kan det oppstå store motsetninger. Årsakene til dette går jeg ikke nærmere inn på her. Mange flyktninger kan ha gode grunner til ikke å ha dannet noe nettverk. Å bruke sosiale nettverk som diagnostisk forklaring kan derfor i mange tilfeller vise seg å være et feilgrep. Flyktninger unngår kanskje nettverket nettopp for å beskytte seg selv. På tross av dette framhever behandlerne at nettverk og nettverksetablering alltid vil være aktuelt. Flere informanter ser det som verdifullt å få kjennskap til flyktningenes tidligere nettverksstruktur, familietilknytning og vennskapsrelasjoner i arbeidet med flyktningenes nåværende nettverk. Det er ikke til å komme bort fra at mange flyktninger lider under sterk ensomhet i Norge og at dette kanskje er en av hovedårsakene til at de utvikler psykiske lidelser.

\section{Arbeidsløshet}

De behandlerne som har uttalt seg i undersøkelsen mener at de fleste flyktninger som befinner seg i det psykiatriske behandlingsapparatet har vær ute av arbeidsmarkedet i lang tid. De har bare hatt korte arbeidsoppdrag som har hatt lite med profesjon, evner, eller interesser å gjøre. Denne utrygge økonomiske situasjonen oppleves som truende på familiens samhold og fører til dårlig selvtillit for den som definerer seg som familieforsørger. Videre er det en stor belastning for vedkommende sin sosiale status og personlige identitet. Mange flyktninger forsørger også slektninger i hjemlandet eller i andre land, noe som er en økonomisk og mental merbelastning når de økonomiske ressursene i familien er knappe. Arbeidsplassen er en arena hvor flyktningene har anledning til å snakke norsk og samhandle med nordmenn. Tap av arbeidsplass går hardt ut over familier med stor forsørgerbyrde, men rammer også enslige flyktninger som ikke har et familienettverk rundt seg.

\section{Identitet}

Arbeid og det å kunne utøve et yrke, er nært forbundet med selvfølelse og identitet. I mange land er håndverkstradisjoner knyttet opp mot familietradisjon, slik det også var i Norge før i tiden. Utøvelse av håndverk og forsørgerrollen er to viktige aspekter ved den maskuline identiteten i mange land. Tap av slike identifiseringspunkter, kombinert med store endringer i livspraksis, er en enorm påkjenning og utfordring for de flyktningene som rammes av dette. Selvsagt er det ikke bare håndverkere som blir påvirket av en slik situasjon. Uansett er arbeidsledighet over lang tid, kombinert med en grunnleggende sårbar situasjon, en utfordring noen takler, men som får andre til å gå til grunne. En psykolog sa som følger: «Flyktningene som kommer til Norge har i utgangspunktet få forventninger til levestandard utover det å forbedre sin livssituasjon. Den vestlige levestandard og den norske velferdsstaten påvirker imidlertid dem som kommer hit og får opphold her. Kjøpepresset gjør noe med dem, deres barn og tenåringer. Arbeidsledighet er en felles svøpe som deles med nordmenn, men flyktningene sliter med store belastninger som kommer i tillegg til denne».

Det å kunne møte flyktninger som har slike og tilsvarende problemer er en viktig utfordring i psykiatrien. Identitetsproblematikken er helt sentral i behandlingen av flyktninger, og den kan være både komplisert og omfattende. Dette vil jeg ikke gå videre inn på i denne artikkelen, men det handler blant annet om endringer i atferd og praksis som påkledning, matvaner, livsstil, sosial samhandling og religiøs praksis.

\section{Mistillit}

Mange flyktninger synes å ha utviklet psykiske lidelser i eksil. Ofte blir den norske konteksten oppgitt som årsak til problemene. Som en av psykologene sa: «Noen flyktninger har utviklet en grunnleggende mistillit til mennesker. De føler seg uten fortid og kan ikke se noen framtid. Det menneskelige sikkerhetsnettet mangler ofte helt eller har gått i oppløsning. Konsekvensen er en sterk misnøye med seg selv og med majoritetssamfunnet. Mistilliten kan også rette seg mot egne landsmenn og forhold innad i den nasjonale eller etniske gruppen. Det skal mye kunnskap og erfaring til for å avdekke årsaker til flyktningers opplevelse av mistillit, og noen kunne kanskje fått hjelp på et tidligere tidspunkt etter at de kom til Norge.

\section{Kjønn}

Samtaler med fagpersoner innen det psykiske helsevernet har vist at det kommer flere menn til behandling enn kvinner. En lege mener at: «Selv om vi får relativt få kvinnelig pasienter tror jeg likevel mange av dem har psykiske vansker. Muligens holder de seg hjemme og lider i stillhet. Kvinnenes lidelser kommer ofte til uttrykk på andre måter enn hos menn. Flere kvinner som har opplevd politisk vold, som ofte innebærer voldtekt, bærer denne opplevelsen inni seg. Det kan være vanskelig for helsevesenet å oppdage dette før kvinnen eventuelt utvikler alvorlige psykiske lidelser».

\section{Avslutning}

Med undersøkelsene fra 1995-1996, og oppfølgingen i 2011, har jeg søkt å få innsikt i noe av den kunnskap, erfaring, informasjon og de tanker som behandlere og andre fagpersoner innen psykisk helsevern besitter om pasienter med flyktningbakgrunn. Informantene som inngår i dette materialet har tilknytning til de institusjonene som mottar flest flyktninger til behandling i regionen. Informantene representerer ulike grupper behandlere. Intensjonen med undersøkelsen var å gi et bilde av møtet mellom flyktning og behandler og de utfordringer og dilemmaer som gjerne oppstår i møtet mellom dem. Selv om det er et terapeutisk møte, er det også et kulturmøte. De siste 30 årene er det hentet inn mye erfaring fra arbeidet med flyktninger innen helsevesenet, og det er gjort undersøkelser og forskning på det psykososiale området. Behandlere og fagpersoner i helsevesenet, og særlig innen psykisk helsevern, mener at de mangler basiskunnskap om pasienter med flyktningbakgrunn og deres livssituasjon i Norge. De savner særlig kunnskap om kulturelle forhold. Grunnleggende kunnskap om flyktningenes bakgrunnshistorier er viktig for å forstå konteksten deres - både den de befant seg i i hjemlandet og den norske. IIII

\footnotetext{
LITTERATUR

Ahlberg N. På flukt fra virkeligheten med eller uten retur. Noen kulturpsykologiske synspunkter på muslimske flyktninger Tidsskrift for Kirke og Kultur 1991. Hefte nr. 4: 309-315

2. Akman H. Landflyktighet En etnologisk undersakelse av vietnamesiske flyktninger i eksil. Bergen: Bergen. Migrasjonsforlaget, 1995.

Andersen $\mathrm{H}$, Roland AD. Etniske minoriteter: kulturmøder i sundhedsvæsnet. København: Munksgaard, 2001

København: Munksgaard, 2001.
Austveg B. Helsearbeid og innvandrere. Oslo: Tano, 1989.

5. Hauff E. (1989): Psykososiale konsekvenser blant flyktninger. Tidsskrift for den norske legeforening. 1989. Nr. 17-18: 867-70

6. Kemp C, Rasbridge LA. Refugee and immigrant health: a handbook for healt professionals. Cambridge: Cambridge University Press, 2004.

7. Lavik NJ, Sveaas N. Psykososial konsekvenser av organisert vold. Noen inntrykk fra Latin- Amerika. Tidsskr nor legeforen 1990. Nr. 17: 253-7
} 